\author{
What Determines the Extent of Fiscal Decentralization? The Russian Paradox
}

\author{
Lev Freinkman ${ }^{1}$ and Alexander Plekhanov ${ }^{2}$
}

\begin{abstract}
$^{3}$
The paper provides an empirical analysis of the determinants of fiscal decentralization within Russian regions in 1994-2001. The conventional view that more decentralized governments are found in regions/countries with higher income, higher ethnolinguistic fractionalization, and higher levels of democracy is not supported by the data. This motivates a more refined analysis of the determinants of decentralization that points to the link between decentralization and the structure of regional government revenue: access to windfall revenues leads to a more centralized governance structure. The degree of decentralization also depends positively on the level of urbanization and regional size and negatively on income and general regional development indicators such as the education level.
\end{abstract}

Key words: Decentralization, local government, fiscal federalism

JEL classification: H1, H7

World Bank Policy Research Working Paper 3710, September 2005

The Policy Research Working Paper Series disseminates the findings of work in progress to encourage the exchange of ideas about development issues. An objective of the series is to get the findings out quickly, even if the presentations are less than fully polished. The papers carry the names of the authors and should be cited accordingly. The findings, interpretations, and conclusions expressed in this paper are entirely those of the authors. They do not necessarily represent the view of the World Bank, its Executive Directors, or the countries they represent. Policy Research Working Papers are available online at http://econ.worldbank.org.

\footnotetext{
${ }^{1}$ World Bank. Email: 1freinkman@worldbank.org

2 Faculty of Economics, University of Cambridge, Sidgwick Avenue, Cambridge, CB3 9DD, UK. Email: ap339@cam.ac.uk.

${ }^{3}$ The authors are grateful to Toke Aidt, John Litwack, Stepan Titov, and Daniel Treisman for valuable comments.
} 


\section{What Determines the Extent of Fiscal Decentralization? The Russian Paradox}

\section{Introduction}

Why are some countries highly decentralized while others are not? And in particular, what determines the degree of fiscal decentralization, i.e., the decentralization of government spending? The benefits and perils of decentralization have been actively studied both theoretically and empirically; however, few studies have attempted to construct and empirically test the positive theory of fiscal decentralization. A general consensus that emerged from several cross-country empirical studies (most notably Oates, 1972, Pommerehne, 1977, and Panizza, 1999) pointed toward four main determinants of fiscal decentralization: larger size, higher income per capita, higher ethnolinguistic fractionalization, and higher level of democracy.

Large federations (such as the United States, Brazil, India or Russia) provide a valuable opportunity to analyze the determinants of fiscal decentralization at the regional level ${ }^{4}$. Such analysis is in many ways similar to a cross-country analysis since regions in large federations are often as large as independent states; they enjoy sufficiently high fiscal autonomy and arguably are under the influence of the same decentralization drivers as independent states.

This paper tests the hypotheses about the determinants of fiscal decentralization using data on regions in Russia from the 1990s to the early 2000s. Russian regions constitute an interesting sample for studying the determinants of decentralization for four main reasons. Firstly, cross-country studies of the determinants of decentralization inevitably run into difficulties when trying to control for unobserved heterogeneity. Moreover, the choice of a specific sample of countries often influences the results and data are not necessarily consistent across countries since the methods and standards of data collection vary. In the case of Russia, though present, unobserved heterogeneity is arguably less of a problem, the sample choice is well defined and the data are collected and reported using the same methods and standards. Secondly, Russian regions

\footnotetext{
${ }^{4}$ Fiscal decentralization at the regional level is conventionally measured by the ratio of municipal government expenditure to general regional government expenditure.
} 
retain sufficient sovereignty in their decentralization choices - that is, they have broad powers to decide on the allocation of budget funds between municipal governments and the (central) government of each region, "regional government" hereafter (see Freinkman et al., 1999). Thirdly, for the sample of Russian regions all variables of interest have remarkably high variation, comparable to that in a cross-country sample. For instance, the ratio of the minimum to maximum per capita gross regional product [GRP] exceeds 30 times (see Table 1). Population, land area, and ethnic heterogeneity also vary considerably across regions. At the same time, democratic traditions appear to be more uniform due to the 500 years of common history of a highly centralized state.

Finally, studying decentralization in Russian regions has one more specific advantage related to the short history of Russian decentralization. As Panizza (1999) noted, although the equilibrium degree of decentralization could be a function of several variables (income, size, etc., as predicted by the models), the actual observable degree of decentralization is also a product of historical circumstances, and it exhibits high inertia. As a result, the main factors determining the observed differences in the degree of decentralization could be intrinsically unobserved and immeasurable. However, in the case of Russia, such effects of path dependency and unobserved factors are much less of an issue. This is because the observed degree of decentralization in Russian regions is de facto an outcome not of a long evolutionary development, but of the explicit choice made by regional authorities in response to a simultaneous structural shock associated with the collapse of the Soviet Union. That shock demolished the existing highly centralized structure of governance and enabled regional authorities to tailor their governance structures in line with their local preferences during the extended period of weak central government that has followed.

Apart from the seminal works of Oates (1972) and Panizza (1999) mentioned above, a number of other empirical studies looked at the determinants of fiscal decentralization. Wallis 
and Oates (1988) found for the sample of the US states that only population and urbanization variables robustly positively affected the degree of fiscal decentralization at the state level. Patsouratis (1990) studied fiscal decentralization in a sample of 11 EU countries and reported robust positive effects of population size and per capita income variables. Inter-American Development Bank (1997) looked at fiscal decentralization in a small sample of Latin American countries and found that larger country size, larger population, formally federal structure, and better development of democratic institutions were conducive to fiscal decentralization. Arzaghi and Henderson (2005) studied the determinants of fiscal decentralization in 41 countries (looking only at government consumption as opposed to total government expenditure) and found that fiscal decentralization was associated with higher per capita income, smaller size of the main metropolitan area, formally federal structure, and higher levels of democracy. For a more detailed review of the empirical literature, see Cerniglia (2003) and Letelier (2005).

Freinkman and Yossifov (1999) first studied the determinants of fiscal decentralization in Russian regions and found for the period of 1994-96 that historically more developed regions and regions with lower inflation tended to be more decentralized. This paper extends the analysis of Freinkman and Yossifov (1999) to cover an expanded time interval and, more importantly, to check a much more developed set of decentralization hypotheses. At the same time, the paper intends to apply to Russia the framework developed by Wallis and Oates (1988) for the analysis of decentralization in the United States.

Our initial statistical analysis revealed that the conventional hypothesis about the determinants of fiscal decentralization fails with the Russian regional data. Two coefficients in our base model (income and ethnolinguistic fractionalization) are significant but of the strictly opposite signs relative to the priors. Another core variable (democratization) remains statistically insignificant. Only urbanization and regional size variables have the hypothesized signs and are statistically significant in most specifications. This finding encouraged further analysis that points 
to the importance of the structure of regional budget revenues -- government revenues coming from the mineral resource sector and from federal transfers (i.e., "windfall" revenues) tend to be much less shared with municipal governments than more conventional regional revenues. Thus, the degree of regional fiscal decentralization is decreasing in the share of "windfall" revenues in regional budgets. These results also shed some light on the origins of the flypaper effect supporting the hypothesis that it can be explained by general behavioral principles as suggested by Hines and Thaler (1995). Lower decentralization was also found to be associated with a higher proportion of university students in the regional population and unfavorable attitude of regional governments to reforms in general. When controlling for these additional factors, ethnolinguistic fractionalization loses its explanatory power, but regional size, urbanization and income variables retain their significance and sign. That is, higher regional income is still associated with less decentralization of regional fiscal systems.

The paper is structured as follows. Section II presents a brief overview of the conventional theory of the determinants of decentralization and tests it on the Russian data. Section III discusses and tests the alternative hypotheses about the determinants of decentralization. Section IV concludes.

\section{The Russian Paradox}

2.1. The determinants of decentralization. The collapse of the Soviet Union in 1991 constituted a major decentralization shock: the share of subnational government in general government expenditure increased from about 15 percent in the late 1980 s to over 50 percent in the mid 1990s (Freinkman and Haney, 1997). Moreover, against the general background of downsizing of the general government in Russia, consolidated subnational budget expenditure increased in absolute terms: municipal and regional government expenditure grew by 3.1 percent of GDP and 2.4 percent of GDP respectively over 1992-97, while the federal budget contracted by 21.6 percent of GDP over the same period. Faced with such rapid decentralization, different 
regions adopted very different models of splitting the expenditure between municipal and regional government levels.

What could explain these differences given similar starting points for all regions? The following five factors are commonly believed to affect the choice of the extent of fiscal decentralization.

1. Size. According to Oates (1972), local governments can have both consumer and producer advantages over the central government. Consumer advantage is due to the fact that local provision of public goods and services can better match the diverse preferences of the local population. The producer advantage is due to asymmetric information: local governments can collect more precise information about the cost and benefits of local projects and thus provide public goods in a more cost-efficient way. Since the benefits from matching heterogeneous preferences are more significant when the regional population/area is large and diverse, the degree of decentralization is expected to increase with the size of the country (region) ${ }^{5}$.

2. Ethnic fractionalization. For the same reason the degree of decentralization is also expected to increase in relation to ethnic fractionalization.

3. Level of democracy. The argument that more democratic states tend to be more decentralized rests on the plausible assumption that the degree of fiscal decentralization is eventually decided by the central authorities since taxation tends to be substantially more centralized than expenditure in all countries and in particular in Russia, and legislative powers also rest with the central authorities. With developed democratic institutions central authorities accept a higher degree of fiscal decentralization since they care more about better matching preferences of voters through local decision making. ${ }^{6}$

\footnotetext{
${ }^{5}$ Previous studies generally confirmed this hypothesis with the exception of Stegarescu (2004) who reports negative impact of population on fiscal decentralization in a sample of 32 OECD countries. However this may be simply caused by omission of fixed time effects in panel fixed effects estimation.

${ }^{6}$ Panizza (1999) incorporates this argument into his model of the choice of the degree of decentralization.
} 
4. Income. The subtlest argument refers to the role of per capita income. Following Wheare (1964), decentralization is often viewed as a luxury good since, as Prud'homme (1995) argues, at low levels of income the basic needs of the population are universal and require no fine preference matching, while as income grows people start demanding different kinds of public goods. Oates (1972) and Panizza (1999) indeed find evidence of a positive correlation between per capita income and fiscal decentralization. Wallis and Oates (1988) on the contrary find no such evidence for the USA states and argue that the relationship can be reversed in rich countries: as societies become richer, they pay more attention to equalization of wealth, which is usually implemented by fiscal redistribution through central government transfers. Combining the two arguments and viewing Russia as a medium-income country, one would expect a positive relationship between income and fiscal decentralization in Russian regions.

5. Urbanization. Wallis and Oates (1988) found that urbanization is associated with higher fiscal decentralization. As the size of municipalities grows, they become able to provide a wider range of public goods and services, which could not be provided within small rural communities. The study by the Inter-American Development Bank (1997) finds that among categories of government expenditure the most decentralized are urban transportation, water supply, waste and urban street management. In the course of urbanization the weight of these expenditure items in total government spending grows rapidly, facilitating overall fiscal decentralization. World Bank (2000) report suggests that decentralization may be viewed as a means of maintaining political stability when pressures for more autonomy become stronger. Insofar as educated middle class emerging in cities becomes more exposed to global aspirations and voices demand for more autonomy, urbanization may contribute to decentralization. Besides, 
urbanization can affect the degree of decentralization in the long run indirectly, via its contribution to income growth and democratization. ${ }^{7}$

Finally, several studies (Inter-American Development Bank, 1997, Cerniglia, 2003, Arzaghi and Henderson, 2005) confirmed that a formal federal structure contributes to higher fiscal decentralization; however such constitutional considerations do not apply to the analysis at the regional level.

2.2. Fiscal decentralization in Russian regions. Russia is a federal state, in which the governments of 89 regions have broad powers with respect to their fiscal policies, particularly the level and structure of budget spending. Regional governments are free to decide on such important elements of expenditure policies as the levels of salaries of civil servants in sectors financed from subnational budgets, subsidies to state-owned enterprises and to households, or the level of social benefits.

The organization of regional fiscal systems and in particular the assignment of expenditure responsibilities to municipal and regional governments, until very recently was largely determined by regional governments themselves. There was little federal regulation on this issue and regions had the opportunity to develop different decentralization models. Moreover, in the 1990s, the Russian central government was quite weak and regional elites had de facto even more freedom of decision making than a broad federalist legal framework would suggest. Most importantly, regional governments were empowered to make frequent changes to the "rules of the game" (Freinkman et al., 1999).

Starting from 2000 much effort has been made by Putin's administration to strengthen central government control over the regions and a number of laws regulating subnational finance came into force, aimed at improving uniformity in subnational fiscal arrangements (see Institute

\footnotetext{
${ }^{7}$ In spite of the strong theoretical support for the urbanization hypothesis, unlike the first four determinants of fiscal decentralization, its analysis is ignored by many empirical studies. Also, Letelier (2005) reports a negative effect of urbanization in a sample of 64 countries.
} 
for the Economy in Transition (2004) for more details). Therefore, the period before 2001 is particularly well suited for the study of the determinants of decentralization.

2.3. Testing strategy. The 5 hypotheses can now be tested for Russian regions. The dependent variable, the degree of fiscal decentralization [DEC], can be measured either as a share of municipal government expenditure in general (consolidated) regional government expenditure or as a share of municipal government revenue in general regional government revenue. The former is preferred since the justification of most hypotheses is based on arguments about spending rather than revenue generation. ${ }^{8}$ Figure 1 shows the trend for the average degree of fiscal decentralization within Russian regions over the period.

The size of a region [SIZE] can be measured either in terms of population or in terms of area. The former approach relates better to the matching heterogeneous preferences argument. However, the latter measure is also commonly used in the literature and relates directly to the notion of inter-jurisdictional spillovers. One of the obvious costs of decentralized decision making is the potential failure to internalize positive and negative effects of policies in one region on the welfare of the inhabitants of the neighboring regions. Arguably, the extent of such potential spillovers declines as distances become larger and therefore the costs of decentralization due to unaccounted spillovers will be lower in larger states.

\footnotetext{
${ }^{8}$ Using expenditure also ensures better comparability of findings with those of previous studies. While some authors look at both expenditure and revenue measures, others, for instance, Inter-American Development Bank (1997) and Arzaghi and Henderson (2005), examine expenditure only. Also, as Wallis and Oates (1988) point out, the measures of expenditure decentralization tend to be more stable over time compared to measures of revenue decentralization.
} 


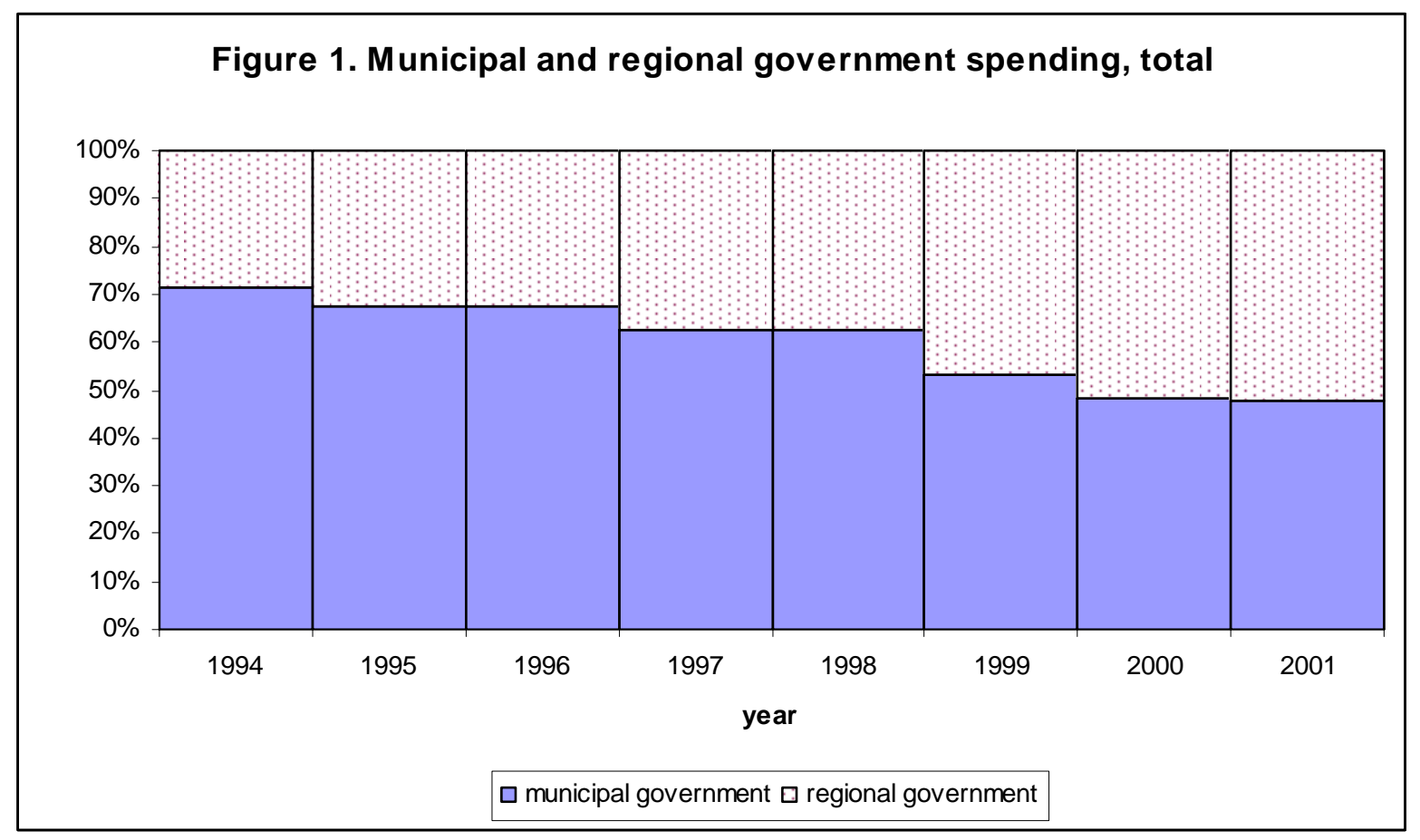

Income can be measured using per capita GRP in real terms ${ }^{9}$. An alternative (purchasing power parity [PPP] adjusted) measure of income takes into account the fact that the purchasing power of the Russian rouble differs greatly across regions. These differences are reflected in highly varying figures of the regional subsistence minimum, a minimum monthly per capita income required to survive (according to the Russian Statistical Agency, see Table 1). Since the bundle of goods underlying the calculation of the subsistence minima is the same across regions, by dividing per capita GRP by the subsistence minimum one obtains a PPP adjusted measure of per capita income (expressed as a multiple of the annual subsistence minimum). Both indicators are used to check the robustness of the results.

Ethnolinguistic fractionalization $[E L F]$ is measured using the conventional ELF index, a number between 0 and 1 showing the probability that two randomly selected individuals belong to different ethnolinguistic groups. Higher values of the index correspond to higher population heterogeneity. The ELF index was used by Mauro (1995) and by many subsequent cross-country

\footnotetext{
${ }^{9}$ Converted to 2000 prices using region-specific consumer price indices since regional specific GRP deflators are unavailable.
} 
studies of growth, and also by Panizza (1999). ${ }^{10}$ For Russian regions this measure has not been readily available and was constructed using the data from the 1989 census. ${ }^{11}$

Urbanization [URBAN] is conventionally measured by the percentage of the urban population.

The most challenging task is to construct a region-specific measure of democracy [DEM]. Most cross-country studies (including Panizza, 1999) use the Gastil (1990) index of democracy and political rights or similar survey-based indices. Unfortunately such indices are unavailable for Russian regions. Instead, two proxies for the regional level of democracy are considered.

The first proxy is based on electoral statistics and equals the spread between the percentage of votes for the winner and for the runner-up in the first round of the elections of regional executive. ${ }^{12}$ Certainly, tense electoral competition is neither a necessary nor sufficient condition for developed democracy; however, on average one would expect a high positive correlation between the competitiveness of elections and the quality of democratic institutions. For the sample of 38 presidential democracies the correlation between the percentage of votes that the head of state got in the first round of the last elections prior to 2000 and the Gastil index of democracy in 2000 is $0.53 .^{13}$

The second proxy is based on the only currently available survey-based study of the institutional environment in Russian regions carried out by an independent international organization, namely the corruption perception index compiled by Transparency International for 40 Russian regions in 2001-02. Once again, the perception of corruption and the perception of

\footnotetext{
${ }^{10}$ Earlier studies (e.g., Oates, 1972) distinguished between heterogeneous and homogeneous states by using a dummy variable.

${ }^{11}$ Ethnic fractionalization may have plausibly increased during the 1990s as a result of significant external migration and various shocks. However, we did not have access to the data from the latest (2002) Russian census.

${ }^{12}$ Electoral rules vary across regions. In some regions a simple majority is not sufficient for victory and unless one candidate gets more than 50 percent of votes a second round of elections is called between the two candidates who obtained most votes in the first round. Hence, only the first round spreads are comparable across regions.

${ }^{13}$ Authors' calculations based on the World Bank Database of Political Indicators. Higher values of Gastil Index correspond to lower levels of democracy and political freedom. Unfortunately the data on the runner-up votes are not readily available for a broad sample of countries, leaving the above comparison approximate.
} 
political freedom are not perfectly correlated, but the correlation is expected to be highly positive. For the sample of 89 countries for which data are available for 2000 , the correlation between the negative of the corruption perception index and the Gastil index is $0.66 .{ }^{14}$

The fact that the correlation between the Gastil index and the two available proxies, albeit strong, is far from being perfect should not be viewed as disappointing since the Gastil index itself is an imperfect discrete measure of the underlying concept of democracy.

The equation to be estimated is thus:

$$
D E C_{i t}=\alpha+\beta G R P_{i t}+\gamma E L F_{i}+\delta D E M_{i t}+\lambda S I Z E_{i t}+\mu U R B A N_{i t}+\varepsilon_{i t}
$$

Since this study focuses on the long-term determinants of the degree of fiscal decentralization rather than on explaining short-term deviations from the mean, equation (1) is estimated by applying the between panel estimator that exploits the cross-sectional variation of the time averages for each region. ${ }^{15}$

2.4. Data. To test the five hypotheses, we assembled a new dataset on Russian regions. The data cover the period 1994-2001 and 86 Russian regions (the cities of Moscow and St. Petersburg are excluded as incomparable with the rest of the regions for the purpose of the analysis; and Chechnya is excluded due to data unavailability). ${ }^{16}$ The data are taken mostly from official Russian statistical yearbooks and the Ministry of Finance database and augmented from other sources listed in Appendix 1. The data for certain years and regions are unavailable, for

\footnotetext{
${ }^{14}$ Higher values of the corruption perception index compiled by Transparency International correspond to lower corruption and hence the negative of the index is taken.

${ }^{15}$ See Wooldridge (2002) for details.

${ }^{16}$ The data before 1994 are unreliable due to hyperinflation and poor coverage (e.g., GRPs were not computed). The period after 2001 appears to be characterized by much stronger centralization, particularly in the political sense, so that the degree of fiscal decentralization within a region can no longer be thought of as chosen almost entirely at the discretion of regional authorities.
} 
instance GRP was not computed for autonomous districts before 2000 (with the exception of Chukotka).

Table 1 shows some descriptive statistics for the main variables of interest. ${ }^{17}$

2.5. Basic results. The results obtained by estimating equation (1) using the between panel estimator are reported in Table $2 .{ }^{18}$ Specifications $A$ and $C$ use the PPP adjusted measure of GRP whereas specification $B$ checks the robustness of results using the unadjusted real GRP. In addition, the specification $C$ includes the corruption based measure of democracy instead of the competitiveness of regional elections. Since data on these indicators are occasionally missing regressions $A-C$ also differ in subsamples used.

${ }^{17}$ Note that unlike the standard corruption perception index, the corruption perception index values for Russian regions are increasing in the perceived degree of corruption and are explicitly normalized so that the least corrupt region is characterized by value 0 and the most corrupt region is characterized by unity. 100 percent votes spread means that the governor has always been appointed and never elected by a popular vote.

${ }^{18}$ Estimation has been carried out using STATA 8.0. 


\begin{tabular}{|c|c|c|c|c|c|c|c|}
\hline Variable & Mean & $\begin{array}{l}\text { Standard } \\
\text { Deviation } \\
\end{array}$ & Median & Minimum & Maximum & $\begin{array}{c}\text { Coeff. of } \\
\text { variation, } \%\end{array}$ & $\begin{array}{r}\mathrm{N} \\
\mathrm{obs}\end{array}$ \\
\hline $\begin{array}{l}\text { Average degree of expenditure } \\
\text { decentralization, 1995-2001 }\end{array}$ & 0.65 & 0.13 & 0.68 & 0.09 & 0.83 & 20 & 85 \\
\hline $\begin{array}{l}\text { Per capita GRP in 2001, 1,000 current } \\
\text { RUR }\end{array}$ & 52,922 & 65,068 & 34,620 & 10,799 & 400,405 & 123 & 86 \\
\hline $\begin{array}{l}\text { Monthly subsistence minimum in } \\
\text { 2001, current RUR }\end{array}$ & 1,714 & 596 & 1,496 & 1,212 & 4,167 & 35 & 83 \\
\hline $\begin{array}{l}\text { Per capita GRP in } 2001 \text {, multiples of } \\
\text { annual subsistence minimum }\end{array}$ & 2.36 & 2.12 & 1.90 & 0.51 & 13.6 & 90 & 83 \\
\hline $\begin{array}{l}\text { Index of ethnolinguistic } \\
\text { fractionalization, } 1989\end{array}$ & 0.33 & 0.2 & 0.29 & 0.05 & 0.85 & 61 & 86 \\
\hline $\begin{array}{l}\text { Average spread between the votes for } \\
\text { the winner and the runner up in the 1st } \\
\text { round of elections, percentage points } \\
(1994-2001)\end{array}$ & 44.3 & 21.7 & 42 & 1.8 & 100 & 49 & 85 \\
\hline Corruption perception index, 2001 & 0.59 & 0.21 & 0.63 & 0 & 1 & 36 & 37 \\
\hline Area, $1,000 \mathrm{~km}^{2}$ & 239 & 464 & 77 & 8 & 3,103 & 194 & 86 \\
\hline Population in $2001,1,000$ people & 1,552 & 1,273 & 1,252 & 18 & 6,436 & 82 & 86 \\
\hline $\begin{array}{l}\text { Excess budget revenue (net federal } \\
\text { transfers as share of GRP) in } 2001\end{array}$ & -0.02 & 0.13 & -0.04 & -0.71 & 0.51 & 650 & 83 \\
\hline $\begin{array}{l}\text { Average share of fuel industry in } \\
\text { industrial production, } \%\end{array}$ & 13.4 & 21.3 & 5.6 & 0 & 94.6 & 159 & 85 \\
\hline $\begin{array}{l}\text { Share of privatized companies in } \\
\text { retail trade and services as of July } 1 \text {, } \\
1996, \%\end{array}$ & 77.5 & 18.7 & 83.7 & 20.3 & 100 & 24 & 75 \\
\hline $\begin{array}{l}\text { Gini coefficient for personal incomes } \\
\text { in } 2001\end{array}$ & 0.4 & 0.04 & 0.4 & 0.34 & 0.51 & 10 & 83 \\
\hline $\begin{array}{l}\text { Social transfers (excluding pensions) } \\
\text { as \% of incomes in } 1995\end{array}$ & 3.82 & 1.37 & 3.56 & 2.41 & 11.48 & 36 & 76 \\
\hline $\begin{array}{l}\text { Gini coefficient for municipal } \\
\text { government per capita own revenue in } \\
2001\end{array}$ & 0.34 & 0.16 & 0.29 & 0.17 & 0.9 & 47 & 71 \\
\hline $\begin{array}{l}\text { Infant mortality in } 1995 \text {, per } 1,000 \\
\text { children born }\end{array}$ & 19 & 3.9 & 18.3 & 12 & 34 & 21 & 83 \\
\hline Urbanization in 1995 & 66.3 & 15.6 & 67.8 & 0 & 92.4 & 24 & 83 \\
\hline $\begin{array}{l}\text { Number of students per } 10,000 \\
\text { population in } 1995\end{array}$ & 133 & 66 & 136 & 0 & 343 & 50 & 83 \\
\hline $\begin{array}{l}\text { Labor force with university degree in } \\
2001, \%\end{array}$ & 20.3 & 3.9 & 20.1 & 12.2 & 32.5 & 19 & 83 \\
\hline $\begin{array}{l}\text { Spending on infrastructure and } \\
\text { development as \% of regional budget } \\
\text { in } 1998\end{array}$ & 10.3 & 6.7 & 7.7 & 3.1 & 40.0 & 65 & 81 \\
\hline $\begin{array}{l}\text { Spending on infrastructure and } \\
\text { development as \% of regional budget } \\
\text { in } 2001\end{array}$ & 20.0 & 8.7 & 17.7 & 4.6 & 45.2 & 44 & 83 \\
\hline
\end{tabular}

Source: See Appendix 1. 
Regardless of the specification and subsample, three variables are always statistically significant at (at least) the 10 percent level. Firstly, as predicted, the degree of fiscal decentralization increases with the size of the region, although only the effect of the population is always statistically significant. ${ }^{19}$ However, the signs of the other two significant variables contradict the conventional theory: the degree of fiscal decentralization is decreasing in both real per capita GRP and in the index of ethnolinguistic fractionalization. All effects are sizable. For instance, a one standard deviation increase in the index of ethnolinguistic fractionalization ceteris paribus induces a 3.5 percentage point decrease in the degree of fiscal decentralization.

At the same time, as predicted, more urbanized regions tend to be more fiscally decentralized (although statistical significance of the urbanization variable is lost in the small subsample). Measures of democracy are not statistically significant although the observed signs of the coefficients are mutually consistent: negative coefficients on the perceived corruption and the election votes spread both imply a positive relationship between democracy and decentralization. The economic size of the implied effect is also relatively low: a change from an appointment system to the maximum electoral competitiveness with a tie in the first round induces further fiscal decentralization equal to only 4 percent of the total government expenditure.

The use of the corruption perception index in model $C$ provides a good robustness check for the results since the subsample where data on corruption perception are available is random as far as fiscal decentralization is concerned. The results are generally consistent across subsamples and specifications. Using the non-adjusted for PPP income measure in model $B$ brings no significant changes either.

\footnotetext{
${ }^{19}$ This is consistent with the finding of Freinkman and Yossifov (1999) that area is not a robust determinant of fiscal decentralization in Russian regions.
} 


\begin{tabular}{|c|c|c|c|}
\hline \multicolumn{4}{|c|}{ Table 2. Testing 5 hypotheses } \\
\hline Model & $\mathrm{A}$ & $\mathrm{B}$ & $\mathrm{C}$ \\
\hline Estimation Method & \multicolumn{3}{|c|}{ between panel estimator } \\
\hline Dependent variable & \multicolumn{3}{|c|}{ degree of decentralization } \\
\hline $\begin{array}{l}\text { real GRP per capita } \\
\log , \text { PPP adjusted }\end{array}$ & $\begin{array}{c}-0.111 \\
(0.028) * * * \\
\end{array}$ & & $\begin{array}{c}-0.272 \\
(0.064)^{* * * *}\end{array}$ \\
\hline $\begin{array}{l}\text { real GRP per capita } \\
\text { Log }\end{array}$ & & $\begin{array}{c}-0.096 \\
(0.027) * * * \\
\end{array}$ & \\
\hline $\begin{array}{l}\text { Population } \\
\text { Log }\end{array}$ & $\begin{array}{c}0.044 \\
(0.012)^{* * *}\end{array}$ & $\begin{array}{c}0.023 \\
(0.013)^{*}\end{array}$ & $\begin{array}{c}0.070 \\
(0.028)^{* *}\end{array}$ \\
\hline $\begin{array}{l}\text { Area } \\
\text { Log }\end{array}$ & $\begin{array}{c}0.007 \\
(0.010)\end{array}$ & $\begin{array}{c}0.021 \\
(0.011)^{*}\end{array}$ & $\begin{array}{l}-0.002 \\
(0.015)\end{array}$ \\
\hline $\begin{array}{l}\text { Ethnolinguistic } \\
\text { fractionalization }\end{array}$ & $\begin{array}{c}-0.174 \\
(0.067)^{* *}\end{array}$ & $\begin{array}{c}-0.163 \\
(0.066)^{* *}\end{array}$ & $\begin{array}{c}-0.259 \\
(0.107)^{* *}\end{array}$ \\
\hline $\begin{array}{l}\text { Election votes spread in } \\
1 \text { st round }\end{array}$ & $\begin{array}{l}-0.00040 \\
(0.0005)\end{array}$ & $\begin{array}{l}-0.00043 \\
(0.0005) \\
\end{array}$ & \\
\hline Corruption & & & $\begin{array}{l}-0.016 \\
(0.076) \\
\end{array}$ \\
\hline Urbanization & $\begin{array}{c}0.0019 \\
(0.0010)^{*}\end{array}$ & $\begin{array}{c}0.0024 \\
(0.0011)^{* *} \\
\end{array}$ & $\begin{array}{c}0.0014 \\
(0.0018) \\
\end{array}$ \\
\hline Constant & $\begin{array}{c}0.340 \\
(0.099) * * *\end{array}$ & $\begin{array}{c}1.315 \\
(0.255)\end{array}$ & $\begin{array}{c}0.367 \\
(0.226)\end{array}$ \\
\hline number of observations & 546 & 619 & 259 \\
\hline number of groups (regions) & 85 & 85 & 37 \\
\hline $\mathrm{R}^{2}$ between & 0.44 & 0.43 & 0.62 \\
\hline \multicolumn{4}{|c|}{ Notes } \\
\hline $\begin{array}{l}\text { 1. Standard errors in parenth } \\
5 \% \text { with } * * \text {, at } 1 \% \text { with } * * *\end{array}$ & Values signi & $10 \%$ level a & ked with *, at \\
\hline
\end{tabular}

\section{Resolving the Russian Paradox}

3.1. Income and decentralization. The results of the previous section are in sharp contrast with the general consensus about the determinants of decentralization. In particular, with the work of Panizza (1999) who finds that fiscal decentralization is robustly associated with higher per capita incomes, higher ethnolinguistic fractionalization and higher levels of democracy. How can this "Russian paradox" be resolved or explained? Could it be driven by misspecification of the equation (1)? Or is the conventional theory not accurate indeed?

One must first explain the negative association between the measure of fiscal decentralization and per capita income. There can be several explanations for this unexpected relationship. Firstly, as already mentioned, a lower degree of fiscal decentralization in a region 
may be a result of higher local needs for redistributive policies. One would expect regions that do more fiscal redistribution (e.g., regions with a higher share of social transfers in personal income) to have more centralized governments. Whether regions with higher income have more redistributive policies is unclear. In our sample, the pair wise correlation (reported in Table 3 below) suggests the opposite, but in a cross-country context the relationship between income and the extent of fiscal redistribution is likely to be positive.

To test the role of the redistribution factor, four additional variables were considered: the share of social transfers in the average personal income in 1995 (i.e., at the start of the period ${ }^{20}$ ), Gini coefficient for personal incomes measuring income inequality in the region, Gini coefficient for municipal government per capita own revenue measuring horizontal fiscal imbalances in the region, and the share of the population of working age. Since the regional government may be concerned with equalizing both municipal government revenues and personal incomes, our additional variables reflect income inequality at individual and municipal levels. Both Gini coefficients are available only for 2001 , whereas the measure of social transfers is taken as of 1995 to minimize possible reverse causality from fiscal decentralization in the late 1990s to the extent of income redistribution in the region (this reduces the sample to 76 regions since 1995 data for autonomous districts are unavailable). Finally, the demand for redistribution policies is likely to be higher in regions with a higher share of children and elderly people in the population since children and the elderly consume a disproportionately large share of social benefits.

Secondly, it is interesting to test Prud'homme's (1995) argument that the demand for decentralization becomes pronounced only when the basic needs of population are satisfied, i.e., at higher stages of development. ${ }^{21}$ Per capita income is generally rather a noisy reflection of the achieved standard of living and the quality of public goods and services. This is especially true

\footnotetext{
${ }^{20} 1994$ was dropped due to data unavailability. Pensions are not included in social transfers since their share in regional income is determined mostly by demographics.

${ }^{21}$ Analyzing fiscal decentralization in Russian regions Freinkman and Yossifov (1999) report evidence that can be interpreted as supporting this hypothesis.
} 
for Russia as an economy in transition with a high share of incomes generated in the shadow sector, which leads to additional distortions in regional income statistics. An alternative measure of the achieved development level is the infant mortality rate, which also has significant variation across Russian regions and is positively correlated with income. We use both the 1990 figures that reflect the level of initial pre-transition development of each region and the concurrent infant mortality. Alternatively, the indicator of urban landline phone connections is employed (the number of landline phones per 1,000 urban populations). Another important indicator of development achievements is the level of education. We measured it in two ways: using the number of students per 10,000 populations (variable students) and the share of the labor force with university degrees (variable education).

Thirdly, the structure of regional fiscal revenue may matter. It is well known that in intergovernmental relations money tends to stick where it hits, leading to a so-called "flypaper effect". Namely, the elasticity of regional government expenditure with respect to regional income is consistently estimated to be a small fraction of the elasticity of regional government expenditure with respect to central government transfers (the estimates of the latter range from 0.5 to more than unity). ${ }^{22}$ This generally suggests that governments spend "earned" and "unearned" (or "windfall") revenue in different ways. ${ }^{23}$

This would suggest that "earned" revenue could be decentralized in some "normal" way, while windfall revenue is likely to be shared differently, with a much larger share retained by the regional government. In the Russian context one can identify two main sources of windfall regional government revenues: transfers received from the federal government and budget revenue derived from availability of local rents, primarily through implicit and explicit taxation of highly profitable local firms in extraction industries such as oil and gas. The former source

${ }^{22}$ See the survey by Hines and Thaler (1995) and the study by Knight (2002).

${ }^{23}$ Numerous studies (e.g., Blanchard et al., 1994) found the same was true for corporate entities. 
constitutes a major part of government revenue in the poorer regions while the latter is more common in the richer regions.

Measuring the windfall component of transfers in the context of Russian regions is not straightforward. Considering all central government transfers as windfall revenue would considerably overestimate the windfall, since in many cases the "earned" revenue is first transferred to the federal budget and then routinely finds its way back to the region in the form of federal transfers. Transfers can be viewed as genuinely "unearned" only in the case when they result in total regional government expenditure exceeding the total tax collection in the region. Thus, the difference between general regional government expenditure and total tax collection (expressed as a share of GRP) could be considered as a summary measure of regional transfer dependency or in other words, of regional availability of "excess budget revenues". The excess revenue measure is expected to affect the degree of decentralization negatively.

The most important mineral resources in Russia are oil and gas. Therefore, following Desai et al. (2003), the extent to which a regional government has access to rent-related windfall revenue is proxied by the share of fuel industry in the total industrial output in the region. Once again, the constructed measure is expected to be negatively associated with the degree of decentralization. Given the fact that oil and gas extracting regions tend to be significantly richer on average, the hypothized centralization of windfall revenue may explain the observed negative relationship between income and decentralization.

Finally, even after controlling for redistributive policies, the initial level of regional development, and windfall revenues, per capita GRP may still affect the degree of decentralization. If this negative effect persists, it may provide an indirect evidence of an increasing propensity of governments to finance larger scale development projects at higher levels of income, since such projects tend to be financed and implemented in a centralized way by regional governments. 
3.2. Ethnic fractionalization and decentralization. What about the unexpected negative association between ethnolinguistic fractionalization and decentralization? Arzaghi and Henderson (2005), who obtain a similar negative relationship in a cross-country study, explain it by the explicit choice of ethnically diverse countries to preserve a high degree of fiscal centralization in order to minimize the risk of secession (in line with the argument of Easterly and Levine, 1997, and La Porta et al., 1998). However, the secession movement of municipalities within regions, even if not totally unconceivable, is arguably much more limited compared with secession threats by regions in large federations, whereas in our sample the negative relationship between ethnolinguistic fractionalization and decentralization still appears to be very strong.

An alternative explanation of this phenomenon is based on different attitudes of regions to reforms. In Russia, the most ethnolinguistically fractionalized regions are ethnic republics that during the 1990s enjoyed significantly higher decision-making autonomy compared to other (administrative) types of regions. At the same time (and partly as a consequence of the granted autonomy), the ethnic republics pursued reforms much slower on average. As "slow reformers" they inherited a centralized approach to governance compared to more keen reformers. 


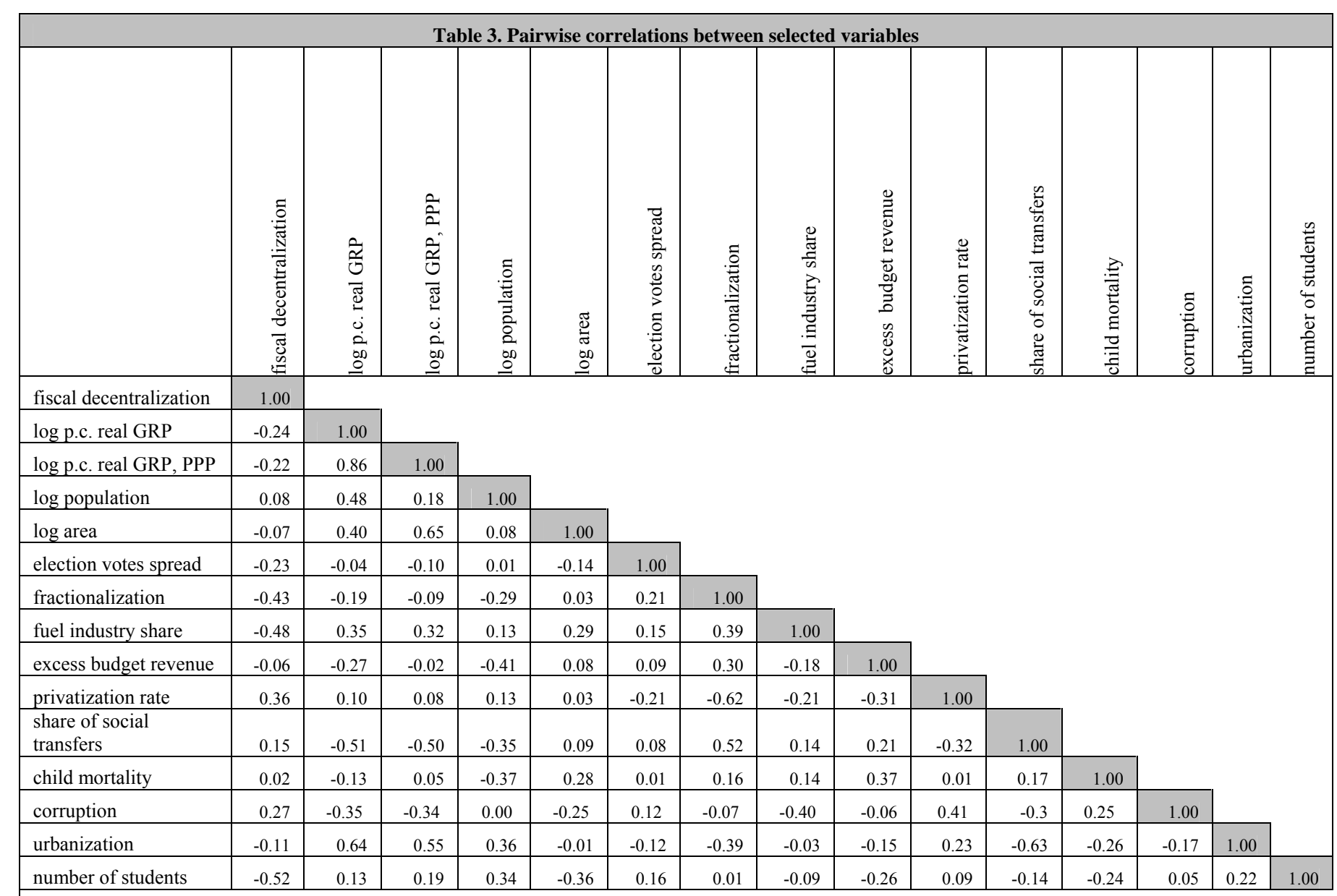

Notes: Based on 1999 unless otherwise indicated in the text

A suitable measure showing how keen regions were on pursuing reforms is the share of privatized enterprises in retail trade and services as of July 1, 1996, i.e., approximately 4 years after the launch of mass privatization. It is a suitable measure because regions did not have a choice of whether or not to participate in the privatization program, but they retained significant discretion over the pace of the privatization process. As a result, the 1996 privatization outcome varied greatly across regions with the share of privatized companies covering the range from 20 percent to 100 percent (see Table 1). As expected, the index of ethnolinguistic fractionalization is highly negatively correlated with the privatization measure of reforms (the coefficient is -0.62 , see Table 3). If this "attitude to reforms" explanation is valid, the privatization variable will be 
positively associated with the degree of regional decentralization and ethnolinguistic fractionalization will lose its explanatory power in the expanded model.

The earlier study by Freinkman and Yossifov (1999) found indirect evidence in support of a similar hypothesis. Namely, fiscal decentralization in Russian regions was negatively associated with inflation in 1994-96. Freinkman and Yossifov argue that inflation in 1994-96 was higher in those regions where it was lower in 1992-93, i.e., in the regions that initially delayed price liberalization and generally were more reluctant to pursue reforms. Arguably, privatization completion provides a more precise measure of the speed of reforms and hence offers a more direct test of this hypothesis.

Panizza (1999) also emphasized the importance of history dependence for the choice of the degree of decentralization and found empirical support for it. However, the test of Panizza and the one in this paper are fundamentally different: Panizza showed that the speed of the change in the degree of decentralization positively depends on the remaining distance between the actual fiscal decentralization and its equilibrium value predicted on the basis of the four main explanatory variables. Inclusion of the privatization variable in this paper, on the contrary, shows that the choice of fiscal decentralization at any point in time may be dependent on other policy choices not incorporated into standard decentralization models.

An alternative explanation of the importance of ethnolinguistic fractionalization rests on the advantageous position of ethnic republics in revenue sharing with the federal government. Treisman (1996) argues that due to a threat of secession, ethnic republics systematically enjoyed higher federal transfers. Indeed the correlation between "excess" budget revenue and ethnolinguistic fractionalization is positive and sizable (0.3), therefore it is important to control for windfall revenues when testing for the effect of being a "slow reformer", as well as for the effect of ethnolinguistic fractionalization. The dummy variable for ethnic republics should also be included. 
Other control variables include the population of the largest city as a share of total population (used by Arzaghi and Henderson (2005) as an alternative proxy for urbanization) and the logarithm of the distance between the regional capital and Moscow (to capture possible geographical patterns in fiscal decentralization). Neither variable proved to be significant.

3.3. Results. Equation (1) was augmented with variables introduced above. Table 3 shows that although some of the selected variables could be expected to be highly correlated (e.g., GRP and infant mortality or urbanization and the population share of the largest city), in fact they are not; and hence there are no serious objections to using them as regressors simultaneously. The results are presented in Table 4. As in Table 1, column $A$ reports the results for our preferred specification, while columns $B$ and $C$ check the robustness of the results by introducing additional control variables (which automatically restrict the available sample).

The hypothesis about the negative impact of windfall revenues on fiscal decentralization is strongly supported. The negative coefficient on the share of the fuel industry is robustly statistically significant in all specifications. It is also economically significant: a 10 percent increase in the share of the fuel industry is associated with 2.2 percent higher fiscal centralization. Excess regional government revenue generated by transfers also has the expected negative sign and is statistically significant in most cases. 


\begin{tabular}{|c|c|c|c|}
\hline \multicolumn{4}{|c|}{ Table 4. Resolving the Russian Paradox } \\
\hline Model & $\mathrm{A}$ & $\mathrm{B}$ & $\mathrm{C}$ \\
\hline Estimation Method & \multicolumn{3}{|c|}{ between panel estimator } \\
\hline Dependent variable & \multicolumn{3}{|c|}{ degree of decentralization } \\
\hline $\begin{array}{l}\text { Real GRP per capita } \\
\text { log, PPP adjusted }\end{array}$ & $\begin{array}{c}-0.192 \\
(0.043)^{* * *}\end{array}$ & & $\begin{array}{c}-0.166 \\
(0.054)^{* * *}\end{array}$ \\
\hline $\begin{array}{l}\text { Real GRP per capita } \\
\log \end{array}$ & & $\begin{array}{c}-0.215 \\
(0.062)^{* * *}\end{array}$ & \\
\hline Fuel industry share & $\begin{array}{c}-0.0022 \\
(0.0008)^{* *}\end{array}$ & $\begin{array}{c}-0.0020 \\
(0.0011)^{*}\end{array}$ & $\begin{array}{c}-0.0026 \\
(0.0009)^{* * *}\end{array}$ \\
\hline Excess budget transfer revenue & $\begin{array}{c}-0.662 \\
(0.242)^{* * *}\end{array}$ & $\begin{array}{l}-0.118 \\
(0.276) \\
\end{array}$ & $\begin{array}{c}-0.639 \\
(0.256)^{* *}\end{array}$ \\
\hline $\begin{array}{l}\text { Social transfers } \\
\text { as share of income in } 1995\end{array}$ & $\begin{array}{c}0.018 \\
(0.013) \\
\end{array}$ & $\begin{array}{c}0.006 \\
(0.018)\end{array}$ & $\begin{array}{c}0.020 \\
(0.014) \\
\end{array}$ \\
\hline Infant mortality & $\begin{array}{c}0.008 \\
(0.004)^{* *} \\
\end{array}$ & & $\begin{array}{c}0.0057 \\
(0.0040) \\
\end{array}$ \\
\hline Infant mortality in 1990 & & $\begin{array}{l}-0.00007 \\
(0.00065)\end{array}$ & \\
\hline $\begin{array}{l}\text { Gini coefficient } \\
\text { (population in 2001) }\end{array}$ & & $\begin{array}{c}0.189 \\
(0.410) \\
\end{array}$ & $\begin{array}{l}-0.007 \\
(0.363)\end{array}$ \\
\hline $\begin{array}{l}\text { Gini coefficient } \\
\text { (municipalities in 2001) }\end{array}$ & & $\begin{array}{c}0.083 \\
(0.085) \\
\end{array}$ & \\
\hline $\begin{array}{l}\text { Ethno-linguistic } \\
\text { fractionalization }\end{array}$ & $\begin{array}{l}-0.021 \\
(0.081)\end{array}$ & $\begin{array}{c}0.043 \\
(0.148)\end{array}$ & $\begin{array}{l}-0.063 \\
(0.135)\end{array}$ \\
\hline Privatization rate in 1996 & $\begin{array}{c}0.0009 \\
(0.0007) \\
\end{array}$ & $\begin{array}{c}0.0019 \\
(0.0010)^{*}\end{array}$ & $\begin{array}{c}0.0009 \\
(0.0008) \\
\end{array}$ \\
\hline Ethnic republic dummy & & $\begin{array}{l}-0.036 \\
(0.057) \\
\end{array}$ & $\begin{array}{c}0.005 \\
(0.047) \\
\end{array}$ \\
\hline $\begin{array}{l}\text { Area } \\
\log \end{array}$ & $\begin{array}{c}0.017 \\
(0.010)^{*} \\
\end{array}$ & $\begin{array}{c}0.033 \\
(0.017)^{*} \\
\end{array}$ & $\begin{array}{c}0.014 \\
(0.014) \\
\end{array}$ \\
\hline $\begin{array}{l}\text { Population } \\
\log \end{array}$ & $\begin{array}{c}0.045 \\
(0.015)^{* * *} \\
\end{array}$ & $\begin{array}{c}0.007 \\
(0.025) \\
\end{array}$ & $\begin{array}{c}0.044 \\
(0.025)^{*}\end{array}$ \\
\hline Urbanization & $\begin{array}{c}0.0031 \\
(0.0011)^{* *}\end{array}$ & $\begin{array}{c}0.0057 \\
(0.0019)^{* * *} \\
\end{array}$ & $\begin{array}{c}0.0036 \\
(0.0017)^{* *}\end{array}$ \\
\hline $\begin{array}{l}\text { Population share } \\
\text { of the largest city }\end{array}$ & & $\begin{array}{l}-0.032 \\
(0.143) \\
\end{array}$ & $\begin{array}{c}0.040 \\
(0.137) \\
\end{array}$ \\
\hline Votes spread in 1st round of elections & $\begin{array}{c}0.00020 \\
(0.00043) \\
\end{array}$ & $\begin{array}{l}-0.00004 \\
(0.00055) \\
\end{array}$ & $\begin{array}{c}0.00013 \\
(0.00045) \\
\end{array}$ \\
\hline Students & $\begin{array}{c}-0.00024 \\
(0.00013)^{*}\end{array}$ & & $\begin{array}{l}-0.00031 \\
(0.00021)\end{array}$ \\
\hline Education & & $\begin{array}{l}-0.0048 \\
(0.0034) \\
\end{array}$ & \\
\hline $\begin{array}{l}\text { Share of population } \\
\text { of working age }\end{array}$ & & & $\begin{array}{l}-0.428 \\
(0.511)\end{array}$ \\
\hline $\begin{array}{l}\text { Distance from Moscow, } \\
\log \end{array}$ & & & $\begin{array}{c}0.019 \\
(0.015) \\
\end{array}$ \\
\hline constant & $\begin{array}{c}0.001 \\
(0.172)\end{array}$ & $\begin{array}{c}2.124 \\
(0.540)\end{array}$ & $\begin{array}{c}0.127 \\
(0.377)\end{array}$ \\
\hline number of observations & 450 & 374 & 449 \\
\hline number of groups (regions) & 76 & 63 & 76 \\
\hline $\mathrm{R}^{2}$ between & 0.58 & 0.57 & 0.60 \\
\hline
\end{tabular}


The hypothesis that stronger redistributive policies are associated with a more centralized government is not supported, with none of the four variables used to test this claim being statistically significant. That being said, it should be noted that the insignificance of the Gini coefficients can be a result of two opposite effects canceling each other out. On the one hand, higher income inequality calls for more intensive redistribution and hence promotes fiscal centralization; on the other hand, as Wallis and Oates (1988) point out, higher Gini coefficients may reflect higher spatial heterogeneity of preferences due to income segregation thus calling for higher fiscal decentralization.

Even when infant mortality is statistically significant, the positive sign of the coefficient is inconsistent with the hypothesis that more developed regions should be more decentralized. The coefficients on the education variables also show that more developed regions tend to be more centralized: the effects of both the number of higher education students and the share of the labor force with university degrees on fiscal decentralization are always negative, the former being statistically significant in some specifications. Furthermore, the negative pairwise correlation coefficient between fiscal decentralization and the number of students per capita is greater than 0.5 in absolute terms.

When controlling for all these factors, the negative coefficient on per capita GRP itself retains remarkably high statistical significance, which is consistent with the hypothesis that higher per capita GRP is associated with more centralization rather than more decentralization. It could be explained by an increased propensity to finance large scale development projects at higher levels of income.

A positive coefficient on the privatization variable suggests that more keen reformers tended to have more decentralized governments (although statistical significance of this result 
varies, the coefficient always has the expected sign and is of similar magnitude). ${ }^{24}$ When controlling for the windfall revenues and the attitude to reforms, the index of ethnolinguistic fractionalization is never statistically significant and randomly switches signs in different specifications, suggesting that in our sample ethnolinguistic fractionalization as such has no direct impact on fiscal decentralization.

As in basic regressions, larger regions in terms of population tend to have more decentralized governments, although when controlling for a large number of other factors, either area or population are always statistically significant, but on their own they lose statistical significance in some specifications. At the same time, the measures of democracy are never significant determinants of the degree of decentralization, nor are other control variables such as the relative size of the largest metropolitan area or the ethnic republic dummy.

Finally, we checked for possible non-linearities in the relationship between decentralization and per capita income. ${ }^{25}$ It may be the case that poorer regions tend to decentralize as income increases while richer regions recentralize as income grows further (or the other way round), in which case the overall negative linear relationship could do a poor job of capturing the non-linear dependence. The sample was split into subsamples of regions with PPP adjusted per capita income below the median (in 1995) and above the median. The coefficients on per capita income in the two subsamples proved to be almost identical $(-0.171$ and -0.153$)$ and highly statistically significant in both cases, so that no evidence of non-linearity has been found. ${ }^{26}$

3.4. Income and decentralization revisited. If the negative impact of income and socioeconomic development on fiscal decentralization could indeed be explained by an increased

\footnotetext{
${ }^{24}$ Several alternative reform indicators were tested (share of housing/utilities costs paid by population as of 2001; ratio of subsidies in agriculture to agricultural output in 1995; share of commodities with regulated prices in retail turnover in 1996; index of price regulation in 1996; index of investment potential in 1997 compiled by the Expert weekly magazine). None of these were statistically significant.

${ }^{25}$ Reflecting the considerable changes that took place in Russia's fiscal policies after the 1998 financial crisis, we also checked if there are any noticeable differences in the results if we look at the data that cover only the latest years of the period, e.g., 2000-01. We found that the results for such a greatly reduced sample generally hold.

${ }^{26}$ Alternative ways of splitting the sample were used with a similar effect.
} 
propensity to finance large scale development projects at higher levels of income and development, one would expect to find wealthier and more advanced regions to invest a higher share of their government revenue in infrastructure and development.

To identify the part of regional government spending earmarked for infrastructure and development projects and to distinguish it from routine expenditure that does not finance major projects and development goals is a challenging task. Certainly there may be different views on what expenditure items should be labeled as infrastructure and development and any such measure will be intrinsically subjective. Our preferred measure of spending on infrastructure aggregated the following expenditure lines of Russian standard budget classification: development of market infrastructure, non-mandated expenditure on education (i.e., spending other than on basic primary, secondary and higher education), roads, transport, telecommunications, information technologies, ecology, construction works, and architecture. Table 1 indicates that this variable ranging from 3 to 45 percent of regional government spending has significant cross-regional variation.

Table 5 presents the results of the between panel regression showing what factors determined the average share of spending on development projects in regional government expenditure in 1998-2001. Consistent with our hypothesis, a higher level of spending is observed in wealthier regions (as proxied by PPP adjusted per capita income) and in more developed regions (as proxied by higher levels of education and lower infant mortality). On the contrary, other important determinants of the degree of fiscal decentralization (such as windfall revenues, privatization rate in 1996 or urbanization) do not seem to have affected spending on development objectives in any significant way. Among other controls that we used, the ethnic republic dummy proved to be statistically significant: ethnic republics spent on average 2.9 percent more on infrastructure and development, other things being equal. Therefore the results in Table 5 indicate that more developed and richer regions were indeed characterized by a higher propensity to spend 
on major publicly financed development projects that called for higher centralization of government expenditure.

\begin{tabular}{|c|c|}
\hline Estimation method & Between panel estimator \\
\hline Dependent variable & $\begin{array}{l}\text { Development spending to regional } \\
\text { government expenditure ratio }\end{array}$ \\
\hline $\begin{array}{l}\text { GRP per capita } \\
\text { Log, PPP adjusted }\end{array}$ & $\begin{array}{c}0.074 \\
(0.018)^{* * *}\end{array}$ \\
\hline Fuel industry share & $\begin{array}{l}-0.000006 \\
(0.00036)\end{array}$ \\
\hline Education & $\begin{array}{c}0.0021 \\
(0.0013)^{*}\end{array}$ \\
\hline Infant mortality & $\begin{array}{l}-0.0028 \\
(0.0015)^{*}\end{array}$ \\
\hline Privatization rate in 1996 & $\begin{array}{l}-0.00008 \\
(0.00031) \\
\end{array}$ \\
\hline Urbanization & $\begin{array}{c}0.0007 \\
(0.0005) \\
\end{array}$ \\
\hline Ethnic republic dummy & $\begin{array}{c}0.029 \\
(0.014)^{* *}\end{array}$ \\
\hline constant & $\begin{array}{c}0.056 \\
(0.057)\end{array}$ \\
\hline Number of regions (groups) & 76 \\
\hline Number of observations & 376 \\
\hline $\mathrm{R}^{2}$ between & 0.44 \\
\hline
\end{tabular}

Unfortunately, given the short time series dimension of the data it is impossible to ascertain whether this phenomenon is permanent or of a transitional nature. The latter may be the case since after the break-up of the Soviet Union Russian regional governments inherited a disproportionately large public sector including public housing and networks of health, education, culture and sport institutions. Following the considerable income declines in the early transition, these assets became unaffordable in most cases at the new real revenue level of the 1990s. However, regional governments were downsizing the inherited infrastructure slowly and often unwillingly. As a result, most regional government spending went on maintenance and operation of the existing social facilities and housing subsidization, while investment and spending on basic infrastructure and development in general remained low. Consequently, only the wealthiest 
regions could afford any significant public investment, centralizing the projects because of the perceived severe shortage of investment funding. Therefore the observed negative dependence between income and fiscal decentralization may to a large extent be a transitional phenomenon, whereby preference for centralization simply reflects the imbalance between large public sector assets and low government revenue, which distorts public expenditure, depresses government investment, and predetermines higher fiscal centralization at higher levels of income and economic development. Indeed, infrastructure and development spending was gradually picking up: the mean share of regional government spending allocated to development objectives increased from 10.3 percent in 1998 to 20 percent in 2001. This increase was widespread and not confined to particular regions since the median also increased from 7.7 percent to 17.7 percent over the same period (see Table 1).

Alternatively, this pattern could result from competition for capital between regions with highly unequal investment potentials, as described by Cai and Treisman (2005). The richer regions actively invest in infrastructure and development in order to attract mobile factors (capital and labor) while poorer regions that are intrinsically unattractive for investors cannot attract much capital whatever their efforts, and hence they choose not to invest in infrastructure. However up to date there is little systematic empirical evidence of such behavior.

Certainly the analysis in this subsection is rather crude and rests on the assumption that spending on regional infrastructure and development does not feed back into regional income in the short run (i.e., income and development indicators can be treated as exogenous). But overall the results indicate rather convincingly that the propensity to finance large scale development projects implemented at the regional level was increasing in income and level of development. However, unfortunately given the data constraints it is not possible to disentangle the permanent and potentially transitional components of this phenomenon. 
3.5. Long-term versus short-term determinants of fiscal decentralization. All the determinants of fiscal decentralization could be classified into the long term (e.g., urbanization, size, level of development, ethnic fractionalization) and the short term ones (attitude to reforms, competitiveness of elections, availability of central government transfers and windfall revenues, etc.). It takes decades for the former factors to change considerably, while the latter can be altered if not overnight than at least within a year.

The analysis shed some light on the relative importance of the short-term and long-term determinants of fiscal decentralization. Of unambiguously long-term factors, three are important determinants of fiscal decentralization: urbanization, size, and higher education traditions (arguably the number of higher education students per capita shows high inertia). However, shortterm factors appear to be equally important, in particular, windfall revenues (both in the form of natural resource rents and intergovernmental transfers), attitude to reforms and per capita income. (We consider per capita GRP as a short-term factor because it was contrasted with the long-term indicators of development, such as infant mortality and education.) Out of the 55 percent of crosssectional variation in fiscal decentralization explained by the model, roughly half ( 30 percent) is explained by long-term factors alone.

Therefore, although the degree of fiscal decentralization is to a large extent determined by long-term developments, it can be substantially influenced in the short run by changing the rules of sharing "windfall" revenues, enhancing economic growth, electing or appointing more reformprone officials, and other measures.

The analysis also suggests that the standard empirical model of decentralization with 4-5 explanatory variables (size, income, ethnolinguistic fractionalization, democracy, and occasionally urbanization and federal status) is likely to be misspecified and suffer from the omitted variables bias. All of the above variables (probably with the exception of income) measure the long-term determinants of fiscal decentralization ignoring the short-term ones. 
3.6. Convergence. A related question is that of how fast regions adjust the extent of fiscal decentralization in response to changes in factors that proved to be important determinants thereof. In other words, do Russian regions converge to the long-run "equilibrium" level of decentralization and what is the pattern of such convergence? Answering this question would require much longer time series than are currently available, but some insights can be obtained from running a dynamic panel regression on the available data.

Convergence to the equilibrium level of decentralization would imply that the extent of fiscal decentralization in a given year depends to a large extent on the historical value inherited from the previous year but also on the current income, windfall revenue, population, urbanization, and level of economic development (other important determinants of fiscal decentralization such as area or measures of attitude to reforms do not have time series variation and therefore do not enter the convergence equation):

$D E C_{i t}=\alpha_{i}+v D E C_{i t-1}+\beta G R P_{i t}+\gamma$ WINDFALL $_{i t}+\delta D E M_{i t}+\lambda \operatorname{SIZE}_{i t}+\mu U R B A N_{i t}+\pi C O N T R O L S_{i t}+f_{t}+\varepsilon_{i t}$

where $\alpha_{i}$ are fixed regional effects and $f_{t}$ are fixed time effects (the full set of year dummies). Specification (2) allows controlling for any time-invariant unobserved heterogeneity among the regions as well as for common shocks such as changes in legislation, financial crises, etc. The latter effects are absorbed by the fixed time effects $f_{t}$.

Estimation of equation (2) by fixed effects results in a bias of order $1 / T$ (where $T$ is the time dimension of the panel, Nickell, 1981). This problem can be circumvented by applying the Arellano-Bond generalized method of moments estimator (Arellano and Bond, 1991). The Arellano-Bond procedure estimates equation (2) in first differences (so that regional fixed effects are cancelled out) using the lagged differences of the dependent variable of order 2 and higher as instruments. 


\begin{tabular}{|l|c|}
\hline \multicolumn{2}{|c|}{ Table 6. Analyzing convergence } \\
\hline \multicolumn{1}{|c|}{ Estimation Method } & Arellano-Bond \\
\hline \multicolumn{1}{|c|}{ Dependent variable } & fiscal decentralization \\
\hline Lagged & 0.275 \\
decentralization & $(0.121)^{* *}$ \\
\hline Real GRP per capita & 0.015 \\
log, PPP adjusted & $(0.029)$ \\
\hline Excess budget transfer & -0.201 \\
revenue & $(0.207)$ \\
\hline Urbanization & 0.006 \\
& $(0.005)$ \\
\hline Population & -0.079 \\
log & $(0.134)$ \\
\hline Infant mortality & -0.003 \\
& $(0.003)$ \\
\hline Students & -0.00003 \\
& $(0.00021)$ \\
\hline Election year & -0.006 \\
& $(0.011)$ \\
\hline Constant & 0.018 \\
& $(0.013)$ \\
\hline Time effects & yes \\
\hline N observations (groups) & $461(81)$ \\
\hline test of 2 order autocor: $\mathrm{z}$-value) & $-0.48(0.63)$ \\
\hline Votes: 1. Robust standard errors in parentheses. \\
5\% -- with **, at 1\% -- with ***. \\
\hline
\end{tabular}

The results are presented in Table $6 .{ }^{27}$ The estimation reveals that fiscal decentralization does not seem to adjust instantaneously to changes in any factors. Namely, one cannot reject the hypothesis that the extent of fiscal decentralization does not adjust to changes in population, urbanization, transfers, income, and development indicators within one year. Convergence to a (new) equilibrium in response to changes in these variables is a lengthy process.

Certainly this result may be partly driven by the generalized method of moments estimation performed on a relatively small sample and thus producing large standard errors. An alternative crude way of looking at the convergence is to analyze the annual changes in average

\footnotetext{
${ }^{27}$ Due to missing data the share of fuel industry in industrial output had to be omitted. The Arellano-Bond estimator may be inconsistent in the presence of the second order autocorrelation in residuals. The null hypothesis of no second order autocorrelation cannot be rejected.
} 
standard errors in panel regressions from Table 4 and to look at $R^{2}$ measures of goodness of fit of year-specific cross-sectional regressions of fiscal decentralization on the same variables as in Table 4 (column $A$ ). Convergence is likely to result in declining mean standard error of the between panel residuals and in increasing $R^{2}$ measure of goodness of fit for individual crosssectional regressions.

However Figure 2 demonstrates that there seems to be no clear increasing or decreasing pattern in the variance of residuals or $R^{2}$ coefficients. $^{28}$ the explanatory power of the chosen determinants of fiscal decentralization neither improves nor deteriorates over time, which also points toward the absence of fast convergence to an "equilibrium" degree of fiscal decentralization.

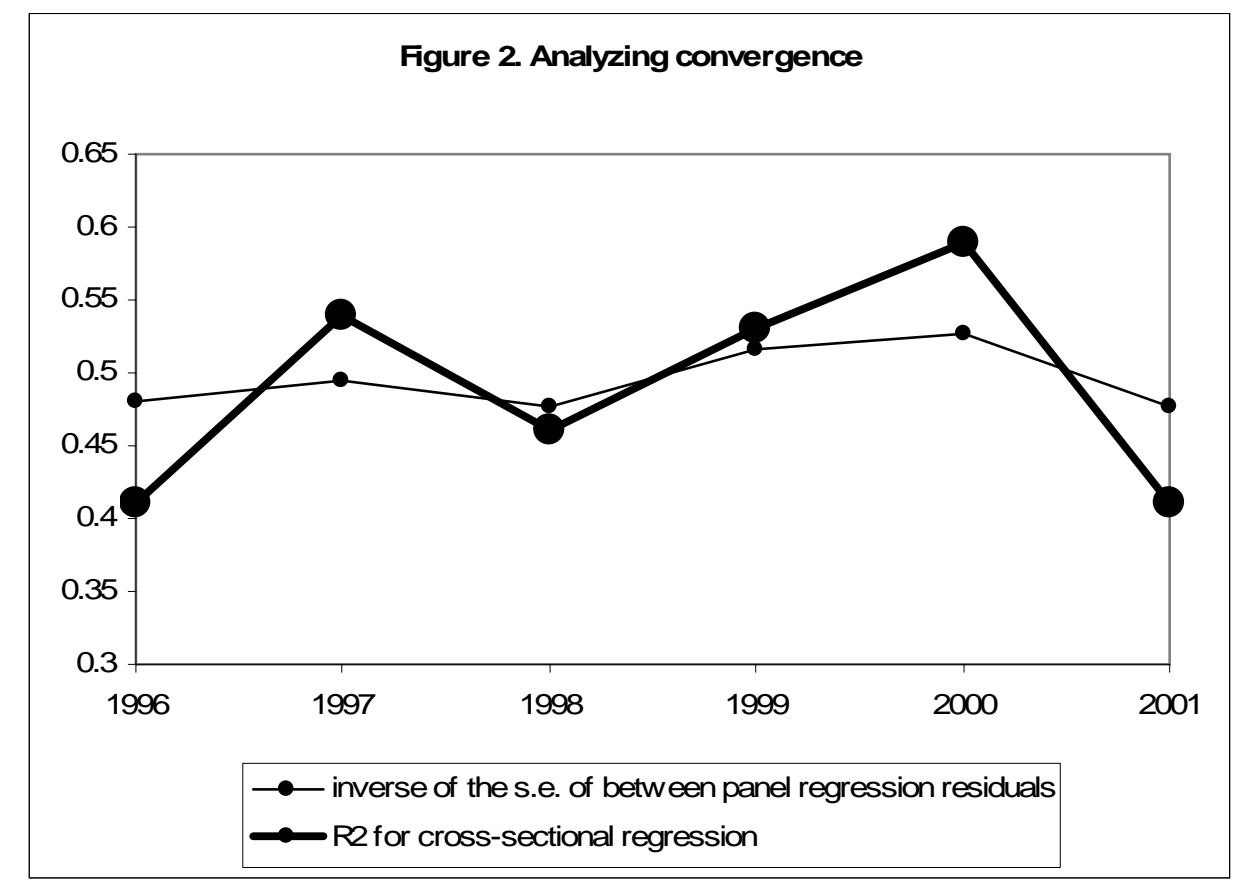

3.7. The flypaper effect revisited. Economists have long been puzzled by a so-called flypaper effect. Following a one dollar increase in regional income regional government spending normally increases by about 10 cents. However should an increase in regional income come in the form of intergovernmental transfer, between 50 and 100 cents of every dollar is spent by the

\footnotetext{
${ }^{28}$ For visible comparability the graph shows the inverse of the mean standard error scaled down by the factor of 20 (since better fit corresponds to higher $\mathrm{R}^{2}$ and lower mean standard error).
} 
government. This phenomenon was called flypaper effect since the money appears to stick where it hits without being redistributed. Such pattern is clearly inconsistent with basic economic theory which suggests that the government maximizing social welfare should allocate available resources optimally between the public and private sectors regardless of the composition of regional income. And yet the flypaper effect is almost universal, having been documented almost in every country. ${ }^{29}$

Hines and Thaler (1995) discuss different explanations of this puzzling regularity. They show that misspecification of econometric models, confusion of average and marginal costs of local government spending projects, high political costs of attracting regional government revenue and other popular explanations advanced in the literature cannot account for the entire magnitude of the flypaper effect although they may have some explanatory power. Hines and Thaler then conclude that the flypaper effect must be a behavioral phenomenon of the "easy come easy go" type: individuals and corporations find it easier to spend quickly unexpected "windfall revenues", and so do governments.

The analysis of fiscal decentralization in Russian regions provided an interesting indirect test of the hypothesis about the behavioral nature of the flypaper effect. Namely, if the theoretical argument of Hines and Thaler is valid, both windfall revenues of the richer regions (derived from natural resources) and those of the poorer regions (in the form of federal transfers) must be spent at the regional rather than municipal level (according to the "money sticks where it hits" principle), negatively affecting the extent of fiscal decentralization.

The estimation shows that it is indeed the case (Table 4). Moreover, under additional assumptions calculations show that effects of windfall revenues in the form of transfers and natural resource rents are comparable: a $1 \%$ increase in the former results in between 0.11 and

\footnotetext{
${ }^{29}$ Hines and Thaler survey the literature studying the flypaper effect mostly in the United States and Canada. However many studies found similar results for other countries. See, for instance, Sagbas and Saruc (2004) on Turkey, Lago-Peñas (2003) on Spain.
} 
0.22 percentage points higher centralization whereas a $1 \%$ increase in "excess" transfers leads on average to 0.19 percentage points additional centralization. ${ }^{30}$ These qualitatively and quantitatively similar estimates support the hypothesis about the behavioral nature of the flypaper effect.

\section{Conclusion}

The traditional positive theory of fiscal decentralization does rather a poor job of explaining the differences in the extent of fiscal decentralization across Russian regions. The coefficients on income and ethnolinguistic fractionalization in the standard base model were statistically significant, but of the strictly opposite sign relative to the priors. Democratization variables were insignificant (although, of course, the available proxies may not capture the concept of democratization particularly well). Within the standard decentralization model, only size and urbanization variables were significant and of expected sign. A more profound analysis points to the structure of regional government revenue as an important determinant of decentralization. Regional government revenues coming from the mineral resource sector and from federal transfers (i.e., "windfall" revenues) tend to be much less shared with municipal governments than more conventional regional revenues. Qualitatively and quantitatively similar effects of rent based and transfer based windfall revenues provided support for the behavioral explanation of the flypaper effect suggested by Hines and Thaler (1995): governments tend to spend "unearned" windfall revenues rather than share them with the lower tier of government or the population of the region in the same way as individuals and corporations find it easier to spend unexpected windfalls.

\footnotetext{
${ }^{30}$ Assuming that a $1 \%$ increase in the share of oil and gas industry translates into an increase in windfall revenue equal to $1 \%$ of regional government revenue, its effect on the extent of fiscal decentralization is $-0.22 \%$. Assuming that oil and gas industry accounts for twice the average industry share in government revenue this effect drops to $0.11 \%$. In regions with excess transfer revenues the general regional government averages $0.29 \%$ GRP. Therefore the effect of an increase in windfall transfer revenue equal to $1 \%$ of the regional budget is on average $-0.66 \% * 0.29=-$ $0.19 \%$.
} 
Lower decentralization was also found to be associated with such development indicators as a higher share of university students in the regional population and lower infant mortality. When controlling for these additional factors, ethnolinguistic fractionalization lost its explanatory power, but regional size and urbanization variables retained their statistical significance and positive sign. In addition, there was some evidence, albeit not very strong, that more keen regional reformers tended to have more decentralized governments compared to slow reformers.

The paper also provides a new insight into the path dependence with respect to the degree of fiscal decentralization. Whereas Panizza (1999) produced an optimistic picture, according to which countries that are further away from the equilibrium level of decentralization converge to it faster, the present paper suggests that exogenous historical and cultural factors that determine a region's attitude to reforms and to change in general can slow down such convergence regardless of the distance from the equilibrium. We found no evidence of convergence, albeit it should be noted that the rather short period of time considered cannot rule out the presence of long-term convergence.

The findings of the paper are only partially consistent with the study of the determinants of fiscal decentralization in Russian regions by Freinkman and Yossifov (1999). While we also found that decentralization is positively associated with favorable attitude to reforms and is not affected by the area, Freinkman and Yossifov's conclusion that more advanced regions tended to opt for higher fiscal decentralization was not confirmed.

On the contrary, the results of the analysis question a widespread view that decentralization is a luxury good, whereby the demand for decentralization increases with income and the level of economic development. The analysis provides evidence (at least for a middleincome country such as Russia) of the higher demand for centralization at higher levels of income and development, possibly driven by two factors: increasing preferences for redistribution of wealth in the society and increasing propensity to finance large-scale publicly-funded 
development projects carried out at the government level above the municipality. Further analysis provided clear evidence only in favor of the latter explanation. However, it would be interesting to check if preferences for redistributive policies result in higher centralization in a cross-country context.

It would also be interesting to test other main results of the paper in the cross-country context, especially the hypothesis that windfall revenues induce higher fiscal centralization. From the normative perspective, whether decentralization is beneficial for countries and regions, where a high share of government revenue is derived from the extraction of mineral resources, is an open question. The recent paper by Desai et al. (2003) provides evidence in favor of more centralized governance in such regions. The rationale is that rent-related government revenues depend very weakly, if at all, on the actions of subnational authorities, and thus higher decentralization does not improve incentives for high quality governance and revenue raising at the subnational level (whereas in the case of more conventional tax revenue, higher decentralization might encourage subnational governments to create better conditions for businesses and to improve revenue collection). However, if fiscal decentralization is viewed as broadly beneficial for development, additional policy measures may be needed to encourage a sufficient degree of fiscal decentralization in countries/regions with a high share of windfall revenues, which otherwise will be more inclined to stay over-centralized.

These results also suggest that grants and loans provided to low and medium-income countries by international donors, which also may be viewed as windfall revenues by the recipients, are unlikely to reach the lower tiers of government and are likely to increase the extent of fiscal centralization. If this effect is to be avoided, a certain fraction of grants/loans must be clearly earmarked for subnational governments. 


\section{References}

Arellano M., Bond S. (1991). Some tests of specification for panel data: Monte Carlo evidence and an application to employment questions, Review of Economic Studies, vol. 58, pp. 277-297.

Arzaghi M., Henderson J.V. (2005) Why countries are fiscally decentralizing, Journal of Public Economics, vol. ?, pp. ??, forthcoming.

Blanchard O.J., Lopez-de-Silanes F., Shleifer A. (1994) What Do Firms Do with Cash Windfalls? Journal of Financial Economics, vol. 36, pp. 337-360.

Cai H., Treisman D. (2005) Does Competition for Capital Discipline Governments? Decentralization, Globalization and Public Policy, American Economic Review, vol. ?, No ?, pp. ?, forthcoming.

Case A., Hines J.R., Rosen H.S. (1993) Budget Spillovers and Fiscal Policy Interdependence: Evidence from the States, Journal of Public Economics, vol. 52, pp. 285-307.

Cerniglia F. (2003) Decentralization in the public sector: quantitative aspects in federal and unitary countries, Journal of Policy Modeling, vol. 25, pp. 745-776.

Desai R.M., Freinkman L.M., Goldberg I., (2003). Fiscal Federalism and Regional Growth. Evidence from the Russian Federation in the 1990s, World Bank Policy Research Working Paper 3138.

Easterly W., Levine R. (1997) Africa's growth tragedy: policies and ethnic divisions, Quarterly Journal of Economics, vol. 112, pp. 1203-1250.

Freinkman L., Haney M. (1997) What Affects the Propensity to Subsidise: Determinants of Budget Subsidies and Transfers Financed by the Russian Regional Governments in 1992-1995, World Bank Working Paper 1818.

Freinkman L., Treisman D., Titov S., (1999) Subnational Budgeting in Russia. Preempting a Potential Crisis, World Bank Technical Paper 452.

Freinkman L., Yossifov P. (1999) Decentralization in Regional Fiscal Systems in Russia. Trends and Links to Economic Performance, World Bank Working Paper 2100.

Gastil R.D. (1990). The comparative survey of freedom: Experience and suggestion, Studies in Comparative International Development, vol. 25, No 1, pp. 25-50.

Hines J.R., Thaler R.H. (1995). The Flypaper Effect, Journal of Economic Perspectives, vol. 9, pp. 217-226.

Institute for the Economy in Transition (2004) Development of the federal and regional law on interbudgetary relations and subnational finance. Brief report, Moscow, IET. [in Russian]

Inter-American Development Bank (1997) Fiscal Decision Making in Decentralized Democracies, in Inter-American Development Bank, Latin America after a Decade of Reforms, Washington, DC, pp. 151-184. 
Knight B. (2002) Endogenous Federal Grants and Crowd-out of State Government Spending: Theory and Evidence from the Federal Highway Aid Program, American Economic Review, vol. 92, No 1, pp. 71-92.

Lago-Peñas S. (2003). Capital grants and regional public investment in Spain: fungibility of aid or crowding-in effect? Studies on the Spanish Economy FEDEA Working Paper 162.

La Porta R., Lopez-de-Silanes F., Shleifer A., Vishny R. (1998) The quality of government, NBER Working Paper 6727.

Lavrov A. (1996), ed., The Budgetary System of the Subjects of the Russian Federation, The Report for the World Bank, Moscow.

Letelier L.S. (2005) Explaining Fiscal Decentralization, Public Finance Review, vol. 33, No 2, pp. 155-183.

Mauro P. (1995) Corruption and Growth, Quarterly Journal of Economics, vol. 110, No 3, pp. 681-712.

Nickell S. (1981) Biases in Dynamic Models with Fixed Effects, Econometrica, vol. 49, No 6, pp. 1417-1426.

Oates W.E. (1972) Fiscal Federalism, NY.

Panizza U. (1999) On the determinants of fiscal centralization: Theory and evidence, Journal of Public Economics, vol. 74, No 1, pp. 97-139.

Patsouratis V.A. (1990) Fiscal decentralization in the EU countries, Public Finance, vol. 45, No 3, pp. 423-439.

Pommerehne W.W. (1977) Quantitative aspects of federalism: A study of six countries, in Oates W.E., ed., The political economy of fiscal federalism: Lexington Books.

Prud'homme R. (1995). The Dangers of Decentralization, World Bank Research Observer, vol. 10, No 2, pp. 201-220.

Sagbas I., Saruc N.T. (2004) Intergovernmental transfers and the flypaper effect in Turkey, Turkish Studies, vol. 5, No 2, pp. 79-92.

Stegarescu D. (2004) Economic Integration and Fiscal Decentralization: Evidence from OECD Countries, ZEW Discussion Paper 04-86.

Treisman D., (1996). The Politics of Intergovernmental Transfers in Post-Soviet Russia, British Journal of Political Science, vol. 26, pp. 299-335.

Wallis J., Oates W.E. (1988) Decentralization in the public sector: An empirical study of state and local government, in Rosen H., ed., Fiscal Federalism: Quantitative Studies, University of Chicago Press, Chicago, IL, pp. 5-28. 
Wheare K. (1964) Federal Government, Oxford University Press, London.

Wooldridge J.M. (2002) Econometric Analysis of Cross-Section and Panel Data, MIT Press.

World Bank (2000) Decentralization: Rethinking Government, Chapter 5, World Development Report 1999/2000, pp. 107-124. 


\section{Appendix 1. Data Sources}

The data are taken from Rossiyskiy Statisticheskiy Ezhegodnik (Russian Statistical Yearbook [RSE]), Goskomstat, Moscow, 2003 and earlier years, with the following exceptions:

Area, region-specific consumer price indices, social transfers, Gini coefficients for personal income, data on education: Regiony Rossii (Regions of Russia [RR], official statistical yearbook), Goskomstat, Moscow, 2002. Gini coefficients are constructed using data on the quintiles of income distribution.

Corruption perception index: Transparency International and Transparency International Russia (available at http://www.transparency.org.ru)

Electoral data for a broad sample of countries: World Bank Database of Political Indicators 2000.

Electoral data for Russian regions: Vybory glav ispolnitelnoy vlasti subyektov Rossiyskoy Federatsii. 1995-1997. Elektoralnaya statistika (1997), Moscow, Ves Mir (The elections of the governors of the regions of the Russian Federation. 1995-1997. Electoral statistics); Vybory v organy gosudarstvennoi vlasti subyektov Rossiskoy Federatsii. 1997-2000. Elektoralnaya statistika (2001), vol. 1-2, Moscow, Ves Mir (Regional authorities elections in the regions of the Russian Federation. 1997-2000. Electoral statistics); Central Election Commission of the Russian Federation (available at http://www.cikrf.ru).

Fiscal data on regional and municipal budgets: Before 1999: Finansy v Rossii (Finance in Russia [FR], official statistical yearbook), Goskomstat, Moscow, 1996, 1998, 2000; World Bank staff. After 2000: Ministry of Finance of the Russian Federation, available at http://www.minfin.ru

Gastil Index: Freedom House (available at http://www.freedomhouse.org)

Gini coefficients for municipal government own revenue: Institute for Fiscal Policy, Moscow.

Share of privatized enterprises in retail trade and services as of 1 July 1996, indices of price regulation, share of government subsidies in agricultural output: Lavrov (1996).

Subsistence minimum: RSE, various years, and World Bank Staff estimates (for 2000).

Tax collection: FR, various years, and the Ministry of Tax Collection (available at http://www.nalog.ru)

Indices of investment potential by regions: Expert, \#39 (398) 19 October 1998 (available at http://www.expert.ru) 
C: $\mid$ Documents and Settings $\backslash w b 81563 \backslash$ My Documents $\backslash L E V F \backslash F i s c a l \backslash R U$ Fiscal Decentralization - Policy Research Working Paper Series Aug 23-2005.doc

09/05/2005 6:39:00 PM 